\title{
Body reserves in intra-African migrants
}

\author{
Chima Josiah Nwaogu ${ }^{1,2,3} \cdot$ Will Cresswell ${ }^{2,3}$
}

Received: 20 January 2015/Revised: 1 June 2015/Accepted: 15 June 2015/Published online: 14 July 2015

(C) The Author(s) 2015. This article is published with open access at Springerlink.com

\begin{abstract}
Avian migration has been shown to be a life history strategy for surviving environmental resource variability, but it requires increased body reserves for long distance flight. Fat reserves make excellent energy stores for barrier crossing, whereas proteins generate less energy for the same mass of fat but provide water during breakdown, which may become especially useful when birds become water stressed. Intra-African migrants are probably unlikely to have to cross barriers equivalent to the Sahara and the Mediterranean sea and so may have different patterns of mass reserves reflecting the utility of metabolizing fat versus protein in hot, tropical environments. We examined differences in proportions of body mass gain, pectoral muscle score, and fat score between intra-African migrants, Palearctic migrants, and resident African species. We tested whether intra-African migrants show a distinct seasonal peak in mass gain corresponding to expected peak migration period in a manner similar to Palearctic migrants, but maintain larger muscle tissues, because Palearctic migrants are more constrained by a need to heavily up-regulate fat in addition to fat-free reserves before migration due to the
\end{abstract}

Communicated by N. Chernetsov.

Chima Josiah Nwaogu

c.j.nwaogu@rug.nl

Will Cresswell

wrlc@st-andrews.ac.uk

1 Groningen Institute for Evolutionary Life Sciences, University of Groningen, P.O. Box 11103 , 9700 CC Groningen, The Netherlands

2 School of Biology, University of St Andrews, Harold Mitchell Building, St Andrews, Fife KY16 9TH, UK

3 A.P. Leventis Ornithological Research Institute, Jos, Nigeria energy requirements of crossing the barrier of the Sahara. We found that intra-African migrants had a peak seasonal mass gain similar to Palearctics whereas African residents did not, and that Palearctics increased fat reserves with pectoral muscle reserves, so that they had much higher fat scores for any given level of pectoral muscle compared to intra-African migrants or resident species. Our results suggest that barrier crossing leads to a distinct increase in fat reserves rather than migration per se, and suggests that intra-African migrants are more similar in their reserve management to African residents. Mass gain devoid of visible fat accumulation in intra-African migrants may, therefore, suggest absence of barriers during migration.

Keywords Avian migration - Intra-African migrants . Energy reserves $\cdot$ Fat storage $\cdot$ Barrier crossing

\section{Zusammenfassung}

\section{Die Körperreserven von innerhalb Afrikas ziehenden Vögeln}

Es ist gezeigt worden, dass der Vogelzug eine Lebensgeschichtsstrategie darstellt, die es ermöglicht, trotz variabler Umweltressourcen $\mathrm{zu}$ überleben, doch werden für den Langstreckenflug größere Körperreserven benötigt. Fettreserven stellen einen exzellente Energiespeicher für das Überwinden von Barrieren dar, während Proteine zwar weniger Energie als dieselbe Menge Fett bereitstellen, aber beim Abbau Wasser freisetzen, was besonders nützlich sein kann, wenn den Vögeln nur wenig Wasser zur Verfügung steht. Zugvögel, die innerhalb Afrikas ziehen, müssen wahrscheinlich keine Barrieren wie die Sahara oder das Mittelmeergebiet überwinden. Sie könnten daher andere Muster von Körpermassereserven aufweisen, welche die 
Nützlichkeit des Verstoffwechselns von Fett im Vergleich zu Proteinen in heißen, tropischen Umwelten widerspiegeln. Wir haben Unterschiede in den Verhältnissen der Körpermassezunahme, der Ausprägung des Brustmuskels und von Fettreserven zwischen intra-afrikanischen Zugvögeln, paläarktischen Zugvögeln und afrikanischen Standvögeln untersucht. Wir haben getestet, ob die Körpermassezunahme intra-afrikanischer Zugvögel einen deutlichen saisonalen Höchstwert zeigt, der mit der erwarteten Hauptzugzeit übereinstimmt, ähnlich wie bei paläarktischen Zugvögeln. Auch haben wir untersucht, ob intra-afrikanische Zugvögel mehr Muskelmasse behalten als paläarktische Zugvögel, die dadurch eingeschränkt sind, dass sie ihre Fettreserven vor dem Zug hochregulieren müssen, um genug Energie für das Überfliegen der Sahara zu haben. Wir fanden heraus, dass die Körpermassezunahme intra-afrikanischer Zugvögel ähnlich wie die paläarktischer Zugvögel einen saisonalen Höchstwert aufwies, was bei afrikanischen Standvögeln nicht der Fall war. Die paläarktischen Zugvögel erhöhten ihre Fettreserven gemeinsam mit der Brustmuskelmasse, wodurch sie für eine gegebene Brustmuskelmasse deutlich höhere Fettspeicher aufwiesen als intra-afrikanische Zugvögel oder afrikanische Standvögel. Unsere Ergebnisse deuten darauf hin, dass das Überwinden von Barrieren und nicht der Zug an sich zu einer deutlichen Zunahme der Fettreserven führt und dass intra-afrikanische Zugvögel in Bezug auf die Regelung der Reserven afrikanischen Standvögeln ähnlicher sind als paläarktischen Zugvögeln. Die bei intraafrikanischen Zugvögeln beobachtete Körpermassezunahme ohne sichtbare Fettanreicherung könnte daher darauf hindeuten, dass sie auf ihrem Zug keine Barrieren überqueren müssen.

\section{Introduction}

Seasonal variability in resources leads to a wide range of survival strategies depending on whether an organism is permanently resident in a particular environment or is a migrant that is capable of utilising opportunities in several environments. Resident birds depend on body reserves during reduced predictability in foraging opportunities, while migratory birds move to environments, which offer predictable foraging opportunities, but still require elevated body reserves to fuel migratory flights (Blem and Power 1990). Therefore, a key adaptation to migration is the optimization of body reserves for increased flight efficiency and management of starvation risk.

The fat component of body reserves may be favoured as 'migration fuel' for its 'weight economy' relative to proteins and carbohydrates (Jenni and Jenni-Eiermann 1998) even though evidence exists that both fat and fat-free reserves are upregulated and broken down during migration (Lindstrom and Piersma 1993; Seewagen and Guglielmo 2011; Hua et al. 2013). Fat reserves make excellent energy stores for barrier crossing and managing starvation prone conditions. In contrast, proteins generate less energy for the same mass of fat but provide more water during breakdown which may become especially useful at low humiditywhen birds may become water stressed (reviewed by Jenni and Jenni-Eiermann 1998). Experiments have confirmed higher breakdown of muscle tissues when birds fly long periods at low humidity (Gerson and Guglielmo 2011a), which suggests that there may be a trade-off between energy production and water balance in the use of either fat or protein as an energy store. The occurrence of nocturnal migratory flights in certain species or individuals also suggests the possible existence of non-fuel constraints to migration (Alerstam 2009; Schmaljohann et al. 2013) or constraints associated with fuel utilisation during migration such as exposure to high temperatures especially when crossing hot deserts during the day (Klaassen 1996).

Body reserves may, therefore, reflect the outcome of trade-offs between efficient flight performance, starvation, and water balance depending on conditions faced during migration. If this is the case, we would expect that variation in the relative use of either fat or protein as energy stores by migrants will give insight into current migratory conditions (Äkesson et al. 1992). It may also suggest how the evolution of migration as a life history strategy influences body reserve storage and utilisation (Bairlein et al. 2013) depending on environmental conditions or the flexibility of migrants (Eikenaar et al. 2014), especially in the face of climate change. We investigate whether temperate barrier-crossing migrants use fat reserves [because they need to optimise range (Jenni-Eiermann et al. 2011)] much more than tropical migrants, which lack similar barriers and so may use protein [because other aspects such as water balance are optimised (Gerson and Guglielmo 2011a, b)]. Palearctic migrants that have to cross the Sahara and the Mediterranean Sea (Bayly et al. 2011, 2012) are likely to utilise more fat reserves compared to sub-Saharan intra-African migrants that are likely to experience more or less unbroken habitat (Hockey 2000) that is at least moderately suitable for most species over most of their assumed migration routes.

Variation in body reserves occurs in many resident African species (Cox et al. 2011), and, in particular, there is an increase in mass associated with breeding (Cox and Cresswell 2015, in submission) but mass change associated with moult (Gosler 1994; Fondell et al. 2013; Hogan et al. 2013) has not been investigated in our study area. Seasonal mass variation also occurs in migrants that only show high levels of body reserves just before and during migration and so only for a few weeks of the annual cycle. Although 
these periods are well known for Palearctic migrants, they are less well defined for many intra-African migrants, although usually associated with the onset and finish of the rainy season. We, therefore, consider seasonal variation in body reserves in both Palearctic and intra-African migrants, as well as resident African species as a control, to identify periods of mass gain and the levels of mass gain associated with migration rather than simply baseline seasonal mass variation (Cox et al. 2011). We might expect African residents to show similar patterns of protein use as a reserve compared to intra-African migrants because flight range is not the priority for their reserves.

Generally, we expect migratory birds to optimise body reserves in anticipation of and during species-specific peak migration periods; reflecting the advantages of metabolising fat or protein as migration fuel. We also expect resident African species not to use fat as a reserve store and to maintain much lower levels of the reserves they do use than intra-African migrants use.

Using morphometric data collected over a decade of constant effort mist netting in a seasonal West African savannah environment in North Central Nigeria (see Stevens et al. 2013) we compare migratory relevant body reserve indices (Labocha and Hayes 2012) —body mass, pectoral muscle score and fat score between intra-African migrants, Palearctic migrants, and resident species, to test two hypotheses:

1. Intra-African migrants will show a significant distinct seasonal peak in mass gain corresponding to a peak migration period in a manner similar to Palearctic migrants. Residents will show relatively small amounts of seasonal mass gain.

2. Intra-African migrants will maintain larger muscle tissues relative to Palearctic migrants. Therefore, we would expect higher fat reserves as pectoral muscles reserves increase in Palearctic migrants, but not in intra-African migrants or resident species, and so for Palearctics to have much higher fat scores for any given level of pectoral muscle compared to intraAfrican migrants or resident species.

\section{Methods}

\section{Study species and area}

Birds included in this study were trapped using understory mist nets between November 2001 and December 2013 as part of the A. P. Leventis Ornithological Research Institute's (APLORI) constant effort ringing program. Trapping of birds was concentrated at constant effort ringing sites (CES) at the APLORI's Amurum Forest Reserve on the Jos
Plateau, Nigeria $\left(09^{\circ} 52^{\prime} \mathrm{N}, 08^{\circ} 58^{\prime} \mathrm{E}\right)$. The $\mathrm{CES}$ ringing takes place five times each year. Trapping takes place between 6:00 and 10:00 h each day for 6 consecutive days. There is a single wet and dry season in our study area lasting about 6 months each; the wet season starts in May and ends in October, while the dry season lasts between November and April of the next year. Instead of using the large scale twolevel factor season as obtainable in our study area, we split each season in two given a four-level factor according to Cox et al. (2011), namely; end of dry (February-April), start of wet (May-July), end of wet (August-October), and start of dry (November-January) season. This allows a finer control of mass variation across the year; since mass gain for migration occurs prior to or during migration. Four of the five CES events take place exclusively in each of the four seasons while the last is between the end of dry and the start of wet season (usually between the last week of April and first week of May) - all CES ringing data for our study species were included in the analysis.

The Amurum Forest Reserve consists of four main habitat types: a regenerating guinea savannah woodland, gallery forest, rocky outcrops (inselbergs), and farmland. Much of the land surrounding the reserve, like the reserve itself before 2001, is degraded by anthropogenic pressure from farming, bush fires, and livestock grazing. IntraAfrican migrants occur in both wet and dry seasons in our study area; while individuals of some species are present year-round in our study area, most species arrive at the late end of the dry season or the start of the wet season and depart at the end of the wet season or the early start of the dry season (Table 1). However, the Namaqua Dove, Vinaceous Dove, and Pygmy Sunbirds are available from the end of the wet season to the start of the next wet season. Several species of Palearctic migrants winter in the Amurum Forest Reserve; they arrive at end of the wet season (August-October) and depart on spring migration at the early part of the next wet season (April-May).

We extracted data for 8946 birds from 34 species (Table 1) from the APLORI ringing database. We included recaptured individuals across seasons within the study period as independent observations to increase sample size in our statistical analysis, because mass gain was calculated separately for each season within a year and individuals were likely recaptured in a different season from previous capture (see "Statistical analyses" below). All tropical species trapped within the study area and classified as migrants or having migratory populations according to the Birds of Western Africa (Borrow and Demey 2004) were included in the study as 'migrants'. Six other species, each of Palearctic migrants and tropical resident species trapped within the study period, were included as controls. These species were selected on the basis of sample size in our ringing data, and that they were trapped in at least two seasons. 
Table 1 List of study species with migratory status, species code, number of individuals included in the study per species, and capture periods for each species based on occurrence in the ringing database

\begin{tabular}{|c|c|c|c|c|c|}
\hline Code & Common name & Scientific name & Status & $N$ & Capture period \\
\hline GARWA & Garden Warbler & Sylvia borin & Palearctic & 1746 & August-May \\
\hline WHITE & Common Whitethroat & Sylvia communis & Palearctic & 746 & September-May \\
\hline WILWA & Willow Warbler & Phylloscopus trochilus & Palearctic & 436 & September-April \\
\hline PIEFL & Pied Flycatcher & Ficedula hypoleuca & Palearctic & 317 & September-May \\
\hline WHINC & Whinchat & Saxicola rubeta & Palearctic & 237 & September-May \\
\hline TREPI & Tree Pipit & Anthus trivialis & Palearctic & 214 & September-April \\
\hline AFRTH & African Thrush & Turdus pelios & Migrant & 870 & Year-round \\
\hline SCCSU & Scarlet-chested Sunbird & Chalcomitra senegalensis & Migrant & 792 & Year-round \\
\hline CIBBU & Gosling's Bunting & Emberiza goslingi & Migrant & 481 & Year-round \\
\hline SNCRC & Snowy-crowned Robin-Chat & Cossypha niveicapilla & Migrant & 370 & Year-round \\
\hline BEASU & Beautiful Sunbird & Cynniris pulchellus & Migrant & 239 & March-December \\
\hline AFPFL & African-Paradise Flycatcher & Terpsiphone viridis & Migrant & 94 & Year-round \\
\hline COPSU & Copper Sunbird & Cinnyris cupreus & Migrant & 87 & February-November \\
\hline GRHKI & Grey-headed Kingfisher & Halcyon leucocephala & Migrant & 79 & March-May \\
\hline PYGKI & African Pygmy-Kingfisher & Ceyx pictus & Migrant & 56 & March-October \\
\hline RESCS & Red-shouldered Cuckoo-shrike & Campephaga phoenicea & Migrant & 38 & March-November \\
\hline WHTBE & White-throated Bee-eater & Merops albicollis & Migrant & 30 & May-June \\
\hline PYGSU & Pygmy Sunbird & Hedydipna platurus & Migrant & 29 & October-June \\
\hline LOTNI & Long-tailed Nightjar & Caprimulgus climacurus & Migrant & 28 & March-November \\
\hline DIDCU & Didric Cuckoo & Chrisococcyx caprius & Migrant & 26 & April-November \\
\hline VINDO & Vinaceous Dove & Streptopelia vinacea & Migrant & 26 & November-April \\
\hline VIBST & Violet-backed Starling & Cinnyricinclus leucogaster & Migrant & 26 & March-September \\
\hline REBQU & Red-billed Quelea & Quelea quelea & Migrant & 17 & October-April \\
\hline KLACU & Klaas's Cuckoo & Chrysococcyx klaas & Migrant & 13 & May-October \\
\hline NAMDO & Namaqua Dove & Oena capensis & Migrant & 11 & October-April \\
\hline WODKI & Woodland Kingfisher & Halcyon senegalensis & Migrant & 11 & April-July \\
\hline MALKI & Malachite Kingfisher & Alcedo cristata & Migrant & 11 & May-November \\
\hline REHQU & Red-headed Quelea & Quelea erythrops & Migrant & 5 & June \\
\hline GRBCA & Grey-backed Camaroptera & Camaroptera brevicaudata & Resident & 603 & Year-round \\
\hline VARSU & Variable Sunbird & Cinnyris venustus & Resident & 524 & Year-round \\
\hline GRHSU & Green-headed Sunbird & Cyanomitra verticalis & Resident & 299 & Year-round \\
\hline FAMCH & Familiar Chat & Cercomela familiaris & Resident & 216 & Year-round \\
\hline TAFPR & Tawny-flanked Prinia & Prinia subflava & Resident & 169 & Year-round \\
\hline ROLCI & Rock-loving Cisticola & Cisticola aberrans & Resident & 167 & Year-round \\
\hline
\end{tabular}

\section{Statistical analysis}

Due to caveats associated with use of body condition indices such as mass residuals (Schamber et al. 2009) and given that more detailed methods (Salewski et al. 2009) are more readily applicable to Palearctic migrants because both fat and pectoral muscle scores are highly variable compared to tropical species, we calculated the proportion of actual body mass gained by a bird. We subtracted the minimum species mass from the observed individual mass and divided this value by the species mass range (species maximum mass gain). However, because minimum species body mass from our data could represent a bird in exceptionally poor body condition and not the absolute minimum mass of a species, we validated our method by further calculating and modelling the proportion of mass gain relative to the median species body mass (compare Figs. 1 and 2). The results did not differ significantly; hence, we based our study on body mass deviation from the minimum species body mass, because this can be better related to the maximum possible mass that can be gained by an individual bird (range), and we present only these analyses here.

In our models we controlled for the potential effects of confounding variables on proportion of mass gain. We 


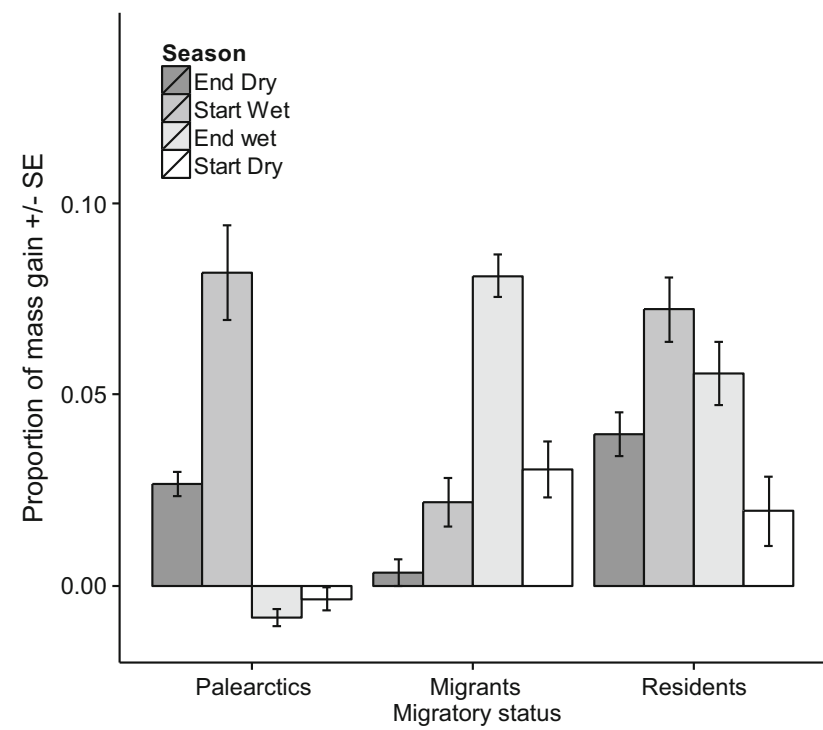

Fig. 1 Difference in proportion of mass gain between Palearctic, Intra-African migrant, and Resident species relative to median mass. Values predicted at mean wing length, fat, and pectoral muscle scores from parameter estimates for model deriving mass gain from median species body mass (statistical table not presented and figure presented to demonstrate the lack of an effect of considering proportion of mass gain relative to median or minimum mass-see Fig. 2)

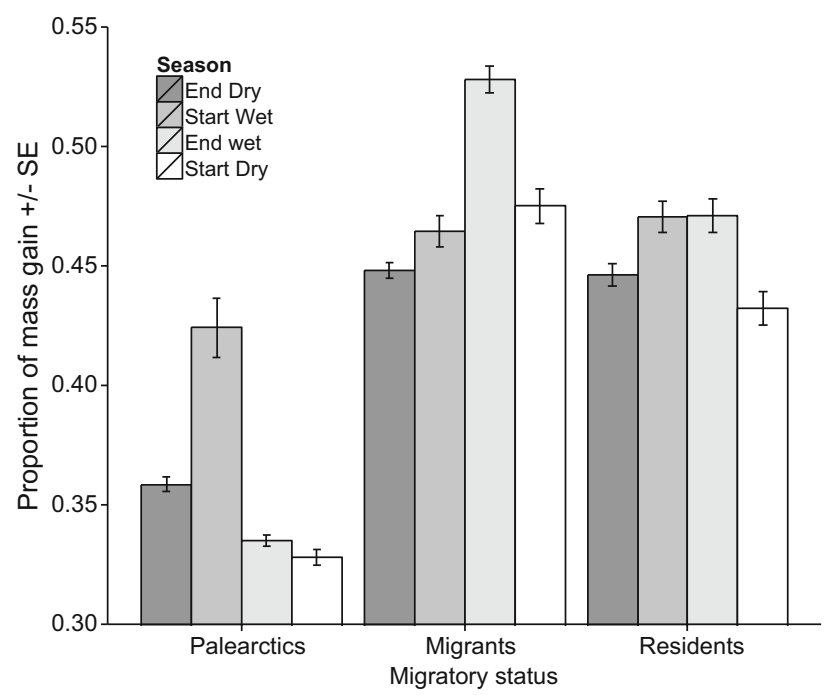

Fig. 2 Difference in proportion of mass gain between Palearctic, Intra-African Migrant, and Resident species relative to minimum mass. Values predicted at mean wing length, fat, and pectoral muscle scores from parameter estimates in Table 1

controlled for the effect of season, fat scores, pectoral muscle scores, and body size. Time of day was ignored because there was little variation with most mass data being collected from birds within $0-2 \mathrm{~h}$ of dawn. The effect of body size was controlled by including wing length as a covariate in models. To ensure homogeneity in variance we modeled variances within migratory status, species, season, and year into the overall model by including these as random effects where they provided a significantly better fit to models. Models were simplified by stepwise removal of non-significant variables, and a minimum adequate model was selected by comparing several models using Analyses of Variance (ANOVA) fit by Restricted Maximum Likelihood (REML). All analyses were carried out in the R (version 3.1.0) statistical environment (R Development Core Team 2011), using the 'nlme' package (Pinheiro et al. 2015).

To test the hypothesis that Intra-African migrants will show a significant distinct seasonal peak in mass gain in a manner similar to Palearctic migrants at peak migration season but not resident species, a Generalized Least Square Model including species, seasons, migratory status, and year as random effects was built. An interaction term between season and migratory status was included in the model to test whether there are seasonal differences in mass gain between the three study groups. While migratory status, species and season improved model fit as random effects, the effect of year did not significantly improve the model fit; hence, it was removed from the minimum adequate model (Table 2).

To test the hypothesis that Intra-African migrants will maintain larger muscle tissues for a given fat score relative to Palearctic migrants, we modelled fat reserves with pectoral muscle scores and migratory status while controlling for seasonal differences. Because fat scores were ordinal; 0 for absence and 9 for maximum fat deposits and also zero inflated by true zero fat scores (absence of visible subcutaneous fat), we modeled fat reserves as count data using a zero-inflated negative binomial model (Hall 2000). The zero-inflated negative binomial model allowed us to separately model the effect of pectoral muscle scores on zero and non-zero fat scores and further model the effect of pectoral muscle scores on the presence and absence of fat using the negative binomial extension of the model. An interaction between pectoral muscle scores and status and pectoral muscle scores and season were included to test whether there were differences in fat scores for any given level of pectoral muscle score across the three study groups, and to test whether differences in fat reserves for a given level of pectoral muscle was consistent across seasons, respectively. We compared zero-inflated negative binomial models with a 'poisson' and one with a binomial link function using 'Irtest' from the 'Imtest' package in R. Finally, we modeled mean species fat scores using mean species pectoral muscle scores (Table 4; Fig. 3) to demonstrate the difference in the relationship between fat and muscle for species within the three study groups using a Generalized Least Square model. The choice of mean species pectoral muscle and fat scores rather than a species median score is due to the fact that most resident and intra- 
Table 2 Summary statistics of a generalized least squares model fitted by restricted maximum likelihood (REML) predicting seasonal mass gain by migratory status using 8198 individuals of 33 species with body mass measured at least across two seasons between 2001 and 2013 in Nigeria

\begin{tabular}{lrrrrrr}
\hline Variable & $d f$ & \multicolumn{1}{l}{$F$} & Estimate & Error & \multicolumn{1}{l}{$t$} & $p$ \\
\hline Intercept & 1 & $1,15,974.2$ & 0.28 & 0.005 & 58.1 & $<\mathbf{0 . 0 0 1}$ \\
Migrant & 2 & 530.5 & 0.09 & 0.005 & 18.8 & $<\mathbf{0 . 0 0 1}$ \\
Resident & & & 0.09 & 0.006 & 15.2 & $<\mathbf{0 . 0 0 1}$ \\
Start wet & 3 & 226.9 & 0.07 & 0.013 & 5.2 & $<\mathbf{0 . 0 0 1}$ \\
End wet & & & -0.02 & 0.004 & -6.1 & $<\mathbf{0 . 0 0 1}$ \\
Start dry & & & -0.03 & 0.004 & -7.2 & $<\mathbf{0 . 0 0 1}$ \\
Fat score & 1 & 3156.6 & 0.04 & 0.001 & 45.2 & $<\mathbf{0 . 0 0 1}$ \\
Pectoral muscle score & 1 & 193.7 & 0.02 & 0.002 & 12.5 & $<\mathbf{0 . 0 0 1}$ \\
Wing length & 1 & 1096.0 & 0.01 & 0.000 & 33.0 & $<\mathbf{0 . 0 0 1}$ \\
Migrant $\times$ start wet & 6 & 38.4 & -0.05 & 0.014 & -3.4 & $<\mathbf{0 . 0 0 1}$ \\
Resident $\times$ start wet & & & -0.04 & 0.015 & -2.8 & $\mathbf{0 . 0 0 5}$ \\
Migrant $\times$ end wet & & & 0.10 & 0.008 & 13.6 & $<\mathbf{0 . 0 0 1}$ \\
Resident $\times$ end wet & & & 0.05 & 0.009 & 5.2 & $<\mathbf{0 . 0 0 1}$ \\
Migrant $\times$ start dry & & & 0.06 & 0.009 & 6.3 & $<\mathbf{0 . 0 0 1}$ \\
Resident $\times$ start dry & & & 0.02 & 0.009 & 1.8 & 0.0735 \\
Residual & & & & 0.070 & & \\
\hline
\end{tabular}

Variances within species, seasons, and status were modelled as random effects. Mass gain $\sim$ status + season + fat + pectoral muscle + wing length + status $\times$ season. Palearctic migrants and end of dry season are set as the intercept in the model

Significant $p$ values are indicated in bold
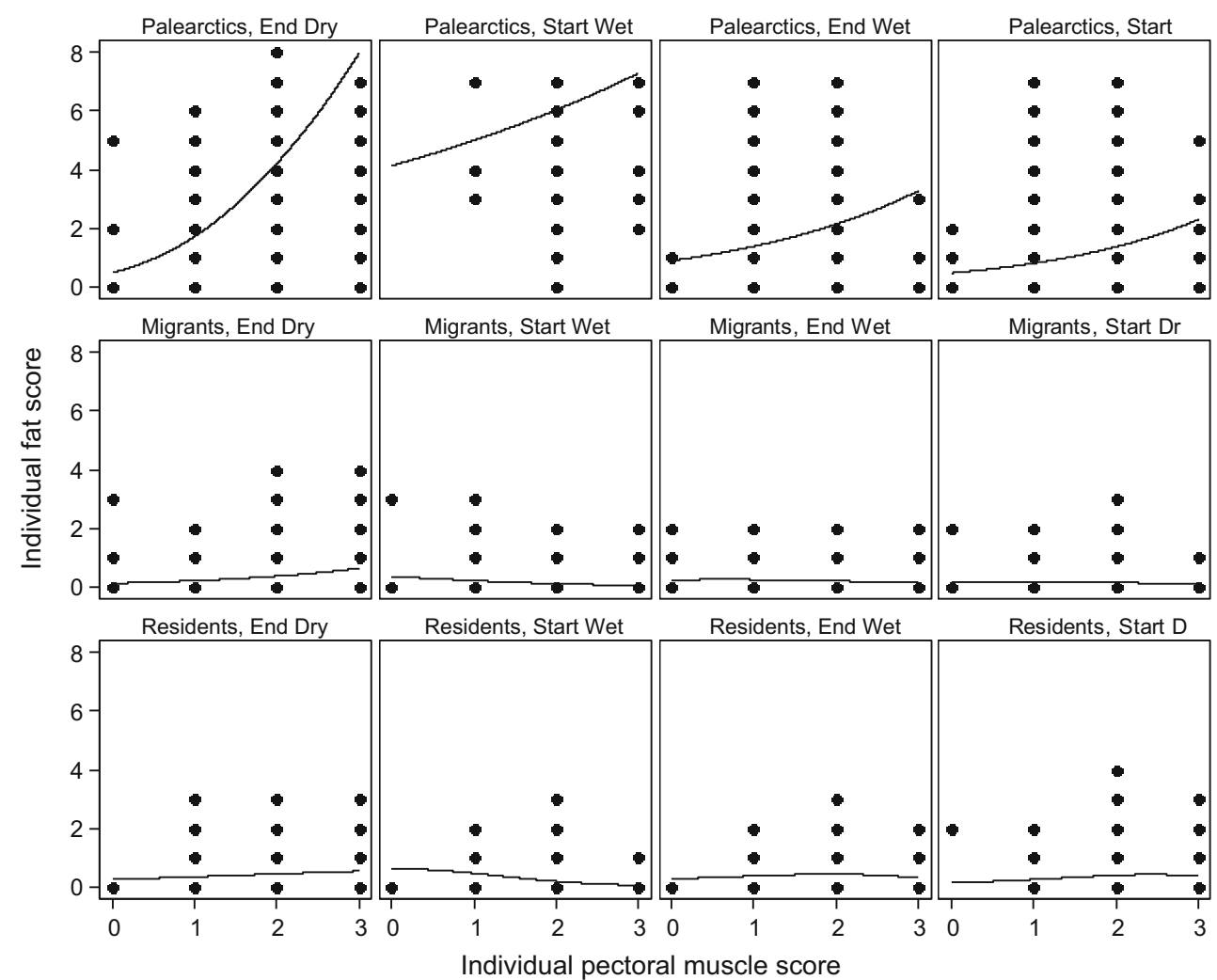

Fig. 3 Relationship between individual fat and pectoral muscle scores for 33 species trapped between 2001 and 2013, Top Palearctic migrants, middle Intra-African migrants, and bottom Resident tropical species. Regression lines were fitted from predictions from a Zero Inflated Negative Binomial model; fat $\sim$ pectoral muscle + status + seasonlpectoral muscle $\times$ status + season 
African migrant species had a fat score of zero, which invariably gives a median score of zero for most species, thus preventing any meaningful comparison.

\section{Results}

\section{Seasonal mass peaks}

Palearctic migrants and intra-African migrants showed a significant clear seasonal peak proportion of body mass gain at the start of the wet season and end of the wet season, respectively (Figs. 1, 2). However, there was a significant difference in the proportion of mass gained by intra-African migrants, Palearctic migrants, and resident species between seasons (see status $\times$ season interaction in Table 2). Both intra-African migrants and resident species maintained a relatively higher proportion of mass gain compared to Palearctic migrants, especially at the end of the wet season and the start of the dry season (Figs. 1, 2). Difference in mass gain between the migratory groups was significantly different between seasons (Fig. 2). Mass gain in resident species was significantly higher in the wet season but not significantly different between the start and the end of the wet season. Intra-African migrants maintained a significantly higher proportion of mass gain compared to the resident tropical species only at the end of the wet season (Fig. 2).

\section{The ratio of fat to pectoral muscle reserves}

The relationship between fat and pectoral muscle scores varied significantly between migratory groups and this was dependent on season (Table 3). Palearctic migrants showed increased fat reserves with increasing pectoral muscles especially at the end of the dry season and the start of the wet season, but there was no significant relationship between fat and pectoral muscle scores for both intraAfrican migrants and resident species in all seasons (Fig. 3). The probability that fat reserves will be present in a bird increases with increase in pectoral muscle score for Palearctic migrants but not for intra-African migrants and resident species (Table 3). Mean species fat scores varied significantly with pectoral muscle scores only for Palearctic migrants (Table 4). Palearctic migrants had a higher mean species fat score for any given pectoral muscle score compared to intra-African migrants and resident species but there was no significant difference between intra-African migrant and resident species (Fig. 4). Overall, intra-African migrants and resident species had similar larger pectoral muscle scores and lower fat scores whereas Palearctic migrants had larger fat scores and lower pectoral muscle scores (Fig. 5).
Table 3 Summary statistics of a minimum adequate zero inflated negative binomial model predicting fat reserve for given pectoral muscle score in Palearctic, Intra-African migrants and resident species from 8198 individuals of 33 species; fat $\sim$ pectoral muscle + status + seasonlpectoral muscle $\times$ status + season

\begin{tabular}{|c|c|c|c|c|}
\hline Variable & Estimate & Error & $z$ & $p$ \\
\hline Intercept & 0.61 & 0.07 & 8.4 & $<0.001$ \\
\hline Pectoral muscle score & 0.25 & 0.03 & 8.1 & $<0.001$ \\
\hline Mass & 0.01 & 0.00 & 6.2 & $<0.001$ \\
\hline Migrants & -1.60 & 0.07 & & $<0.001$ \\
\hline Residents & -1.73 & 0.11 & & $<0.001$ \\
\hline Start of wet season & 0.74 & 0.31 & 2.4 & 0.02 \\
\hline End of wet season & -0.92 & 0.13 & -7.0 & $<0.001$ \\
\hline Start of dry season & -0.26 & 0.12 & -2.2 & $\mathbf{0 . 0 3}$ \\
\hline $\begin{array}{l}\text { Pectoral muscle score } \times \text { start } \\
\text { wet }\end{array}$ & -0.30 & 0.15 & -2.0 & 0.04 \\
\hline $\begin{array}{l}\text { Pectoral muscle score } \times \text { end } \\
\text { wet }\end{array}$ & 0.13 & 0.08 & 1.7 & 0.1 \\
\hline $\begin{array}{l}\text { Pectoral muscle score } \times \text { start } \\
\text { dry }\end{array}$ & -0.11 & 0.07 & -1.6 & 0.11 \\
\hline $\log$ (theta) & 14.54 & & & $<0.001$ \\
\hline \multicolumn{5}{|l|}{ Zero-inflation model coefficients } \\
\hline Intercept & 1.15 & 0.21 & 5.4 & $<0.001$ \\
\hline Pectoral muscle score & -1.26 & 0.12 & -10.2 & $<0.001$ \\
\hline Migrants & -0.29 & 0.31 & -0.9 & 0.4 \\
\hline Residents & -2.04 & 0.66 & -3.1 & $<0.001$ \\
\hline Start of wet season & -5.29 & 2.32 & -2.3 & 0.01 \\
\hline End of wet season & -1.52 & 0.30 & -5.0 & $<0.001$ \\
\hline Start of dry season & -1.45 & 0.31 & -4.7 & $<0.001$ \\
\hline $\begin{array}{l}\text { Pectoral muscle } \\
\text { score } \times \text { migrants }\end{array}$ & 1.16 & 0.16 & 7.5 & $<0.001$ \\
\hline $\begin{array}{l}\text { Pectoral muscle } \\
\text { score } \times \text { residents }\end{array}$ & 1.76 & 0.27 & 6.4 & $<0.001$ \\
\hline $\begin{array}{l}\text { Pectoral muscle score } \times \text { start } \\
\text { wet }\end{array}$ & 1.11 & 0.29 & 3.9 & $<0.001$ \\
\hline $\begin{array}{l}\text { Pectoral muscle score } \times \text { end } \\
\text { wet }\end{array}$ & 1.43 & 0.18 & 8.0 & $<0.001$ \\
\hline $\begin{array}{l}\text { Pectoral muscle score } \times \text { start } \\
\text { wet }\end{array}$ & 1.09 & 0.20 & 5.5 & $<0.001$ \\
\hline Migrants $\times$ start of wet season & 4.76 & 2.22 & 2.1 & $\mathbf{0 . 0 3}$ \\
\hline $\begin{array}{l}\text { Residents } \times \text { start of wet } \\
\text { season }\end{array}$ & 4.51 & 2.23 & 2.0 & 0.01 \\
\hline Migrants $\times$ end of wet season & -1.03 & 0.24 & -4.2 & $<0.001$ \\
\hline Residents $\times$ end of wet season & -3.04 & 0.53 & -5.8 & $<0.001$ \\
\hline Migrants $\times$ start of dry season & -0.57 & 0.29 & -2.0 & 0.05 \\
\hline Resident $\times$ start of dry season & -1.92 & 0.56 & -3.4 & $<0.001$ \\
\hline
\end{tabular}

Palearctic migrants and end of dry season are set as intercept in the model Significant $p$ values are highlighted in bold

\section{Discussion}

Avian migration is undoubtedly an efficient life history strategy for exploiting spatial environmental variability (Alerstam et al. 2003) despite the associated cost of long 
Table 4 Summary statistics of a minimum adequate model for relationship between mean species fat score and mean species pectoral muscle score for 33 species including six Palearctic migrant, six resident, and 21 intra-African migrant bird species trapped between 2001 and 2013

\begin{tabular}{lrrrrrr}
\hline Variable & $d f$ & \multicolumn{1}{c}{$F$} & Estimate & Error & \multicolumn{1}{c}{$t$} & $p$ \\
\hline Intercept & 1 & 148.4 & -3.42 & 2.13 & -1.6 & 0.12 \\
Mean pectoral muscle score & 1 & 0.1 & 3.30 & 1.46 & 2.3 & $\mathbf{0 . 0 3}$ \\
Migrants & 2 & 13.1 & 3.69 & 2.14 & 1.7 & 0.10 \\
Residents & & & 3.30 & 2.14 & 1.5 & 0.14 \\
Mean pectoral muscle score $\times$ migrants & 2 & 3.5 & -3.35 & 1.46 & -2.3 & $\mathbf{0 . 0 3}$ \\
Mean pectoral muscle score $\times$ residents & & & -3.14 & 1.46 & -2.2 & $\mathbf{0 . 0 4}$ \\
Residual & 27 & & & 0.18 & & \\
\hline
\end{tabular}

Status 'Palearctic migrants' is set as intercept in the model

Significant $p$ values are highlighted in bold migratory flights, which requires significant upregulation of body reserves (Jenni and Jenni-Eiermann 1998; Bairlein et al. 2013). Our results confirm that intra-African migrants are 'migrants' similar to Palaearctic migrants by virtue of a clear seasonal mass gain peak in contrast to resident species (Figs. 1, 2), however they do not accumulate fat reserves in a manner similar to Palaearctic migrants (Figs. 3, 4), instead they maintain high pectoral muscle scores similar to resident species (Fig. 5). This difference in reserve strategy may be related to migratory range and lack of large barriers to cross or may reflect a different migratory system for intra-African migrants in terms of evolution and ecology.

\section{Peak seasonal mass gain as an index of migration timing}

In contrast to Palearctic migration, which has been relatively well-studied and defined in relation to conditions in

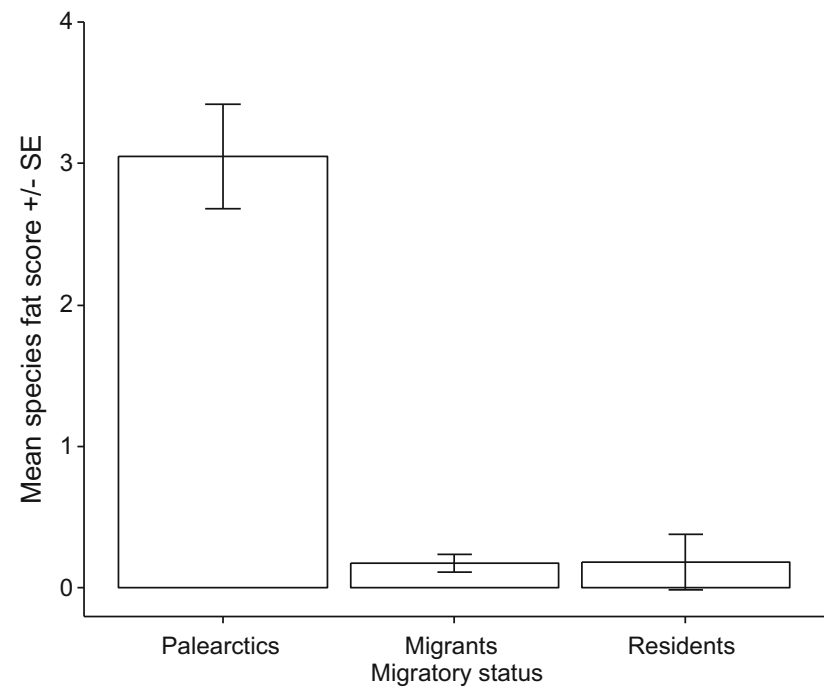

Fig. 4 Difference in predicted mean species fat scores between Palearctic, Intra-African Migrant and Resident species. Values predicted from parameter estimates in Table 4 at mean wing length and pectoral muscle scores wintering and breeding habitats, intra-African migration has been little studied. Our findings (Table 2; Figs. 1, 2) suggest that most intra-African migrants are 'rain' migrants; departing our study area at the end of the wet season. Variation in body mass occurs in tropical birds, and this is especially associated with breeding mass gain (Cox and Cresswell 2015, in submission) and/or seasonality (Cox et al. 2011). The clear single season peak in mass gain proportion observed in Intra-African migrants, despite the relatively higher mass gain by tropical species (Figs. 1, 2), contrasts with the longer duration and less clear mass gain peak in the wet season for resident species (Figs. 1,2). The observed wet season peak mass gain proportion in resident birds may be a result of breeding, which occurs through most of the wet season (see Cox and Cresswell 2015, in submission), especially at the start of the wet (Cox et al. 2013). Mass gain during migration is further evidenced by the fat increase relative to pectoral muscle scores at the end

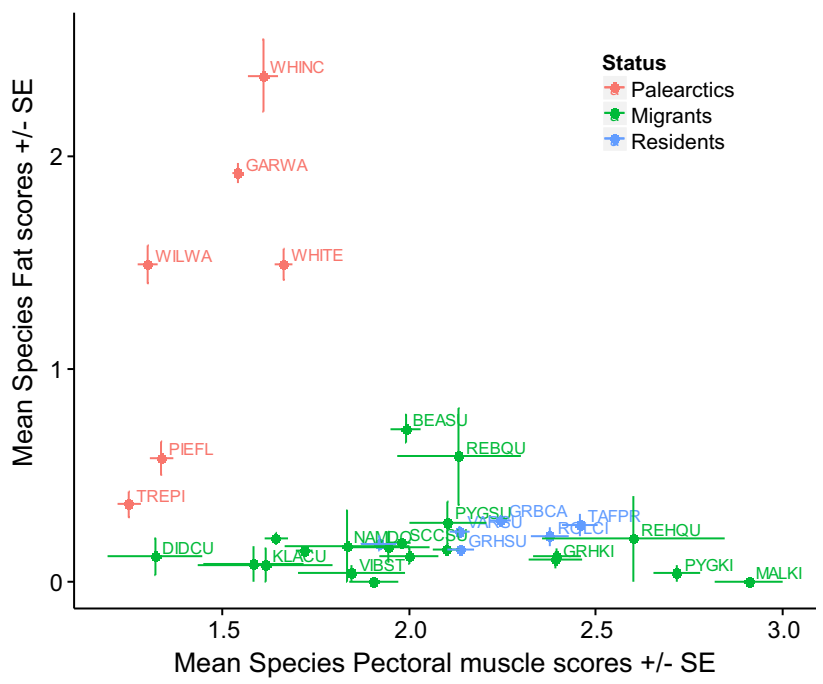

Fig. 5 Relationship between mean species fat score and mean species pectoral muscle score for 33 species trapped between 2001 and 2013, P (red)-Palearctic migrants, M (green)-Intra-African migrants and $\mathrm{R}$ (blue)-Resident tropical species. Species are identified with codes as per Table 1. Some species labels are removed to improve readability 
of the dry season in Palearctic migrants (Fig. 3). The relatively higher mass gain proportion in tropical birds compared to Palearctic migrants except during the migration period is striking. The reason for this difference in mass gain proportion is not clear, but it is unlikely due to size because we controlled the effect of size on mass gain by adding wing length to our model. Nor is it likely to be due to phylogeny, because species such as Grey-backed Camaroptera, Tawny-flanked Prinia that are residents and Snowy-crowned Robin-chats, African Thrushes, and African paradise Flycatchers that are intra-African migrants, are all closely related to the Palearctic migrant species in this study. There is currently very limited understanding on how resident and migratory species vary in response to life history challenges such as predation and starvation within tropical environments, even to the point that predation risk and starvation risk have not been measured systematically. This difference in proportion of body mass gain with migration is likely but not absolutely related to methodology because both the use of species minimum and median body mass as baseline for calculating mass gain resulted in a significant difference between tropical birds and Palearctic migrants at end of the wet season and the start of the dry season (Figs. 1,2). Only Palearctic migrants maintain a proportion of body mass gain lower than the species median body mass at any season. The predicted body mass of Palearctic migrants at the end of the wet and start of the dry season was below median body mass (Fig. 1). Our results suggest that Palearctic migrants may have a different ecology to "African" species during the winter, and this should be investigated in more detail. On the other hand, the weak seasonality in breeding (Cox et al. 2013) and/or moult in tropical savannah may favour the maintenance of high body reserves as adaptive mass gain to deal with interrupted foraging situations during breeding (see Cox and Cresswell 2015, in submission) despite better predictable foraging conditions in the tropics year-round.

\section{Barrier crossing necessitates fat accumulation rather than migration per se}

Varying migration strategies are recorded or speculated about for many species within the African migratory system (Elgood et al. 1973), but how these migrants fit into the avian community of Africa and the evolution of migration is little known (Salewski and Bruderer 2007). Many explanations for the evolution of migration have focused on the geographic origin of Palearctic-African migration (Berthold 1999; Bell 2000, 2005; Rappole and Jones 2002; Rappole 2005). This focus ignores the huge diversity in migratory strategies within geographic groups, which must, therefore, be governed by factors other than geographic origins (Salewski and Bruderer 2007). Although our results confirm that upregulation of body reserves during migration appears to be a common morphological adjustment in both Palearctic and intra-African migrants (Figs. 1, 2), they contrast in the relative accumulation of fat and pectoral muscles (Figs. 3, 4 and 5). Therefore, intra-African migrants appear to be a distinct group due to a reduced fat to pectoral muscle reserve (Fig. 5) and by having low fat levels as pectoral muscles increase (Figs. 3, 4).

The relative higher pectoral muscle scores relative to fat scores in intra-African migrants may suggest the possible absence of barriers, which require long fasting flights. However, pre-migratory fattening in the Red-billed Quelea is accompanied by substantial fat reserve accumulation (Ward and Jones 1977). The level of fat accumulation relates to the migratory distance covered by each migratory race. These distances span an area where grass seeds are unavailable due to the advanced onset of the wet season in the southern part of their migratory range, constituting a significant foraging barrier (Ward 1971). Thus, despite migrating within Africa, Queleas have to fast while migrating until they reach an area where grass seeds are ripe. This similarity in fat accumulation in an African species to Palearctic migrants suggests that barrier crossing necessitates fat accumulation rather than migration. Barriers could put a stop to further migration, result in the evolution of detours, and may lead to changes in fuel deposition and orientation (Alerstam et al. 2003) but the possible role of barriers in the evolution of fat accumulation and utilisation during migration as against other forms of body reserves has not been considered.

Clearly there is a need to find more barrier crossing intra-African migrants and find out whether they have substantial fat reserves and when this fat accumulation takes place during migration like in Palearctic migrants and the Red-billed Quelea. But examining the higher mass gain proportions observed in tropical species (e.g., both migrants and residents in, Figs. 1 and 2) compared to how Palearctic migrants outwit migration, one may infer some independence in the evolution and ecology of intra-African migration compared to Palearctic migration. Furthermore the difference in the season of peak mass gain between Palearctic migrants and tropical migrants may have resulted from differences in seasonal or destination-mediated selection for body reserve utilisation. While it is established that Palearctic migrants are non-breeding visitors that return to breed at higher latitudes, the direction of migration for most tropical migrants remain unclear even though spatial asymmetry is hypothesised due to the large expanse of savannah North and South of the equator (Hockey 2000). This makes it difficult to further support our suggestion of the utility of protein versus fat in intraAfrican migration without further data. However, a comparison of the three groups gives some insight as to 
whether barrier crossing rather than migration itself is driving the evolution of the use of fat as a body reserve during migration in birds.

\section{Use of fat-free reserves may suggest non-fuel costs in avian migration}

The role of oxidative stress caused by physical activity has received little attention in avian migration studies (JenniEiermann et al. 2014) despite its possible impact on life history decisions and energy utilization in birds (Costantini 2008; Monaghan et al. 2009). The effect of reactive oxygen and nitrogen species (RONS) produced by rapid metabolism of body reserves are said to be minimal for birds in good body condition or those with elevated plasma uric acid concentration (Alan and McWilliams 2013)—which may increase when birds catabolize protein instead of fat reserves (Gerson and Guglielmo 2013). Arriving nocturnal migrants at stop over sites with larger pectoral muscle scores showed lower tissue damage and less expression of enzymatic antioxidant capacity (Costantini et al. 2007; Jenni-Eiermann et al. 2014). Whether intra-African migrants are exposed to higher oxidative stress compared to Palearctic migrants during migration is untested. But since barriers similar to those in Palearctic migration may be largely absent for intraAfrican migrants (Hockey 2000), and so range optimization may not be a huge priority as it may be for Palearctic migrants, minimizing oxidative stress and maintaining efficient water balance during migration may be optimized. This may lead to higher pectoral muscle and lower fat reserves in intra-African migrants (Figs. 2,4) if pectoral muscles are the primary protein stores for migrants.

Overall, mass gain during migration may not necessarily equate to an increase in overall or expendable flight fuel for migratory birds. Our observations (Figs. 1, 4), raise questions on the use of increase in overall body mass as an index of fuel load or Fuel Deposition Rate (FDR) during migration (Bairlein et al. 2013), because body reserves accumulated for migration (depending on type) may play non-fuel roles such as for water balance during fasting flights (Gerson and Guglielmo 2011a, b). This is especially important because the energy expended in flight is estimated at less than $30 \%$ of total energy expenditure during migration (Wikelski et al. 2003). Migration presents individual birds with huge uncertainties spread across migratory routes, stopover sites and wintering habitats (Alerstam et al. 2003), thus birds may upregulate different components of body reserve to deal with such uncertainties and not just those associated directly with the energetic flights of migration.

Acknowledgments We thank all ringers who have contributed data to the ringing database. Data analysis and writing was supported by the Mariam Rothschild internship scheme through the Student
Conference on Conservation Science. Samuel Ivande assisted with settling into St. Andrews for data analysis. Thanks to the Editor, Volker Salewski, and an anonymous reviewer for comments that greatly improved the paper. This is contribution number 91 of the A.P. Leventis Ornithological Research Institute.

Open Access This article is distributed under the terms of the Creative Commons Attribution 4.0 International License (http://creativecommons.org/licenses/by/4.0/), which permits unrestricted use, distribution, and reproduction in any medium, provided you give appropriate credit to the original author(s) and the source, provide a link to the Creative Commons license, and indicate if changes were made.

\section{References}

Äke Lindström, Piersma T (1993) Mass changes in migrating birds: the evidence for fat and protein storage re-examined. Ibis 135:70-78

Äkesson S, Karlsson L, Pettersson J, Walinder G (1992) Body composition and migration strategies: a comparison between robins (Erithacus rubecula) from two stop-over sites in Sweden. Vogelwarte 36:188-195

Alan RR, McWilliams SR (2013) Oxidative stress, circulating antioxidants, and dietary preferences in songbirds. Comp Biochem Physiol B: Biochem Mol Biol 164:185-193. doi:10. 1016/j.cbpb.2012.12.005

Alerstam T (2009) Flight by night or day? Optimal daily timing of bird migration. J Theor Biol 258:530-536. doi:10.1016/j.jtbi. 2009.01.020

Alerstam T, Hedenström A, Äkesson S (2003) Long-distance migration: evolution and determinants. Oikos 103:247-260

Bairlein F, Dierschke V, Delingat J et al (2013) Revealing the control of migratory fueling: an integrated approach combining laboratory and field studies in northern wheatears Oenanthe oenanthe. Curr Zool 59(3):381-392

Bayly NJ, Rumsey SJR, Clark JA (2011) Crossing the Sahara desert: migratory strategies of the Grasshopper Warbler Locustella naevia. J Ornithol 152:933-946. doi:10.1007/s10336-011-0676-3

Bayly NJ, Atkinson PW, Rumsey SJR (2012) Fuelling for the Sahara crossing: variation in site use and the onset and rate of spring mass gain by 38 Palearctic migrants in the western Sahel. J Ornithol 153:931-945. doi:10.1007/s10336-012-0823-5

Bell CP (2000) Process in the evolution of bird migration and patterns in avian ecogeography. J Avian Biol 31:258-265

Bell CP (2005) The origin and development of bird migration: comments on Rappole and Jones, and an alternative evolutionary model. Ardea 93:115-123

Berthold P (1999) A comparative theory for the evolution, control and adaptability of avian migration. Ostrich 70:1-11

Blem CR, Power DM (1990) Avian energy storage. In: Current Ornithology, vol 7. Plenum Press, New York, pp 59-113

Borrow N, Demey R (2004) A field guide to the birds of Western Africa. Christopher Helm, London

Costantini D (2008) Oxidative stress in ecology and evolution: lessons from avian studies. Ecol Lett. doi:10.1111/j.1461-0248. 2008.01246.x

Costantini D, Cardinale M, Carere C (2007) Oxidative damage and anti-oxidant capacity in two migratory bird species at a stop-over site. Comp Biochem Physiol Part C Toxicol Pharmacol 144:363-371. doi:10.1016/j.cbpc.2006.11.005

Cox DT, Brandt MJ, McGregor R et al (2011) Patterns of seasonal and yearly mass variation in West African tropical savannah birds. Ibis 153:672-683 
Cox DTC, Brandt MJ, McGregor R et al (2013) The seasonality of breeding in savannah birds of West Africa assessed from brood patch and juvenile occurrence. J Ornithol 154:671-683. doi:10. 1007/s10336-013-0930-y

Cox DTC, Cresswell W (2015) Adaptive mass regulation during breeding: Seasonal mass gain and loss in tropical savannah birds during breeding probably reflects adaptive mass regulation (submitted)

Eikenaar C, Klinner T, de Lille T et al (2014) Fuel loss and flexible fuel deposition rates in a long-distance migrant. Behav Ecol Sociobiol 68:1465-1471. doi:10.1007/s00265-014-1753-4

Elgood JH, Fry CH, Dowsett RJ (1973) African migrants in Nigeria. Ibis 115(3):375-409

Fondell TF, Flint PL, Schmutz JA et al (2013) Variation in body mass dynamics among sites in Black Brant Branta bernicla nigricans supports adaptivity of mass loss during moult. Ibis 155:593-604

Gerson AR, Guglielmo CG (2011a) Flight at low ambient humidity increases protein catabolism in migratory birds. Science 333:1434-1436. doi:10.1126/science.1210449

Gerson AR, Guglielmo CG (2011b) House sparrows (Passer domesticus) increase protein catabolism in response to water restriction. AJP Regul Integr Comp Physiol 300:R925-R930. doi:10. 1152/ajpregu.00701.2010

Gerson AR, Guglielmo CG (2013) Energetics and metabolite profiles during early flight in American robins (Turdus Migratorius). J Comp Physiol B 183:983-991. doi:10.1007/s00360-013-0767-y

Gosler AG (1994) Mass-change during moult in the Great Tit Parus major. Bird Study 41:146-154. doi:10.1080/00063659409477211

Hall DB (2000) Zero-inflated Poisson and binomial regression with random effects: a case study. Biometrics 56:1030-1039

Hockey PA (2000) Patterns and correlates of bird migrations in subSaharan Africa. Emu 100:401-417

Hogan D, Esler D, Thompson JE (2013) Variation in body mass and foraging effort of Barrow's Goldeneyes (Bucephala islandica) during remigial molt. Auk 130:313-322. doi:10.1525/auk.2013. 12048

Hua N, Piersma T, Ma Z (2013) Three-phase fuel deposition in a long-distance migrant, the Red Knot (Calidris canutus piersmai), before the flight to high arctic breeding grounds. PLoS One 8:e62551. doi:10.1371/journal.pone.0062551

Jenni L, Jenni-Eiermann S (1998) Fuel supply and metabolic constraints in migrating birds. J Avian Biol 29:521. doi:10.230 $7 / 3677171$

Jenni-Eiermann S, Almasi B, Maggini I et al (2011) Numbers, foraging and refuelling of passerine migrants at a stopover site in the western Sahara: diverse strategies to cross a desert. J Ornithol 152:113-128. doi:10.1007/s10336-010-0572-2

Jenni-Eiermann S, Jenni L, Smith S, Costantini D (2014) Oxidative stress in endurance flight: an unconsidered factor in bird migration. PLoS One 9:e97650. doi:10.1371/journal.pone.0097650
Klaassen M (1996) Metabolic constraints on long-distance migration in birds. J Exp Biol 199:57-64

Labocha MK, Hayes JP (2012) Morphometric indices of body condition in birds: a review. J Ornithol 153:1-22. doi:10.1007/ s10336-011-0706-1

Monaghan P, Metcalfe NB, Torres R (2009) Oxidative stress as a mediator of life history trade-offs: mechanisms, measurements and interpretation. Ecol Lett 12:75-92. doi:10.1111/j.1461-0248. 2008.01258.x

Pinheiro J, Bates D, DebRoy S, Sarkar D, R Core Team (2015) nlme: linear and nonlinear mixed effects models. $\mathrm{R}$ package version 3.1-120. http://CRAN.R-project.org/package=nlme. Accessed 21 Jan 2015

Rappole JL, Jones P (2002) Evolution of old and new world migratory systems. Ardea 90:525-537

Rappole JH (2005) Evolution of Old and New world migratory systems. Ardea 93:125-131

R Development Core Team (2011) R: A Language and Environment for Statistical Computing. The R Foundation for Statistical Computing, Vienna, Austria

Salewski V, Bruderer B (2007) The evolution of bird migration-a synthesis. Naturwissenschaften 94:268-279. doi:10.1007/s00114006-0186-y

Salewski V, Kery M, Herremans M et al (2009) Estimating fat and protein fuel from fat and muscle scores in passerines. Ibis 151:640-653

Schamber JL, Esler D, Flint PL (2009) Evaluating the validity of using unverified indices of body condition. J Avian Biol 40:49-56. doi:10.1111/j.1600-048X.2008.04462.x

Schmaljohann H, Korner-Nievergelt F, Naef-Daenzer B et al (2013) Stopover optimization in a long-distance migrant: the role of fuel load and nocturnal take-off time in Alaskan northern wheatears (Oenanthe oenanthe). Front Zool 10:26

Seewagen CL, Guglielmo CG (2011) Quantitative magnetic resonance analysis and a morphometric predictive model reveal lean body mass changes in migrating Nearctic-Neotropical passerines. J Comp Physiol B 181:413-421. doi:10.1007/s00360-0100534-2

Stevens MC, Ottosson U, McGregor R et al (2013) Survival rates in West African savanna birds. Ostrich J Afr Ornithol 84:11-25. doi:10.2989/00306525.2013.772544

Ward P (1971) The migration patterns of Quelea quelea in Africa. Ibis 113:275-297

Ward P, Jones PJ (1977) Pre-migratory fattening in three races of the Red-billed quelea Quelea quelea (Aves: Ploceidae), an intratropical migrant. J Zool 181:43-56

Wikelski M, Tarlow EM, Raim A et al (2003) Avian metabolism: costs of migration in free-flying songbirds. Nature 423:704 